\title{
The folding interactome of GPCRs
}

\author{
Christian Bergmayr, Christian Nanoff, Oliver Kudlacek, Michael Freissmuth, Christian W Gruber* \\ From 17th Scientific Symposium of the Austrian Pharmacological Society (APHAR). Joint meeting with the \\ Hungarian Society of Experimental and Clinical Pharmacology (MFT) \\ Innsbruck, Austria. 29-30 September 2011
}

\section{Background}

The $\mathrm{A}_{2 \mathrm{~A}}$ adenosine receptor is a prototypical G proteincoupled receptor. It is expressed in a wide variety of cells including as different types as neurons, platelets, cells of the immune system and muscle. The $\mathrm{A}_{2 \mathrm{~A}}$ receptor has an unusually long $\mathrm{C}$-terminus (of $>120$ residues), which for the most part is dispensable for coupling to $G_{s}$. This $\mathrm{C}$-terminus turned out to be the docking site for other proteins. Using a yeast-2-hybrid screen we have previously identified proteins interacting with the C-terminus including ARNO/cytohesin2, SAP102 and USP4.

\section{Methods}

To verify these interactions in vivo and to identify new interacting proteins of the $\mathrm{A}_{2 \mathrm{~A}}$ adenosine receptor we chose a two-step proteomics approach: we first expressed tagged receptors in HEK293 fibroblasts using various TAP (tandem affinity purification)-tag variants; the differently tagged receptors were analyzed for expression, localization and their pharmacological properties (ligand binding and cAMP accumulation) to identify tags suitable to further analyze the receptor's interactome. These tagged receptors were then used to optimize the purification and to make the first initial screens using 2D-nano-LC-MS/MS approach. To prove the interaction of the $A_{2 A}$ receptor with promising targets found in our screens, biochemical approaches, e.g. co-immunoprecipitation and whole-cell binding, were performed.

\section{Results and conclusions}

We could identify two tags suitable for further analysis of the $\mathrm{A}_{2 \mathrm{~A}}$ adenosine receptor interactome. Pharmacological properties of the tagged receptors were comparable to the native receptor. However, the tags seemed to

\footnotetext{
* Correspondence: christian.w.gruber@meduniwien.ac.at Institute of Pharmacology, Center of Physiology and Pharmacology, Medical University of Vienna, 1090 Vienna, Austria
}

retain the receptor to a large extent in the endoplasmic reticulum (ER) and hence we used this system to study the ER/folding interactome of the receptor. LC-MS/MS analysis of the purified ER-trapped version of the receptor revealed proteins putatively involved in the folding of the receptor, such as chaperones. We are currently generating a transgenic mouse-model expressing the TAP-tagged version of the $\mathrm{A}_{2 \mathrm{~A}}$ adenosine receptor under the control of its endogenous promotors (homologous knock-in). This will allow us to examine tissueand development-specific interaction partners of the $\mathrm{A}_{2 \mathrm{~A}}$ adenosine receptor utilizing the optimized proteomics approach.

Published: 5 September 2011

doi:10.1186/1471-2210-11-S2-A41

Cite this article as: Bergmayr et al:: The folding interactome of GPCRs. BMC Pharmacology 2011 11(Suppl 2):A41.

Submit your next manuscript to BioMed Central and take full advantage of:

- Convenient online submission

- Thorough peer review

- No space constraints or color figure charges

- Immediate publication on acceptance

- Inclusion in PubMed, CAS, Scopus and Google Scholar

- Research which is freely available for redistribution

\section{Biomed Central}

